\title{
RELATIONSHIP OF KNOWLWDGE, ATTITUDES AND BEHAVIOR ABOUT NUTRITION BALANCE WITH NUTRITIONAL STATUS OF STUDENT IN POLTEKKES KEMENKES BENGKULU IN 2020
}

\author{
Thesa Frovela, Desri Suryani, dan Tetes Wahyu \\ Jurusan Gizi, Poltekkes Kemenkes Bengkulu, Jl. Indragiri No 03 Padang Harapan, \\ Bengkulu, 38225 \\ E-mail: frovelathesa@gmail.com
}

Submitted: $13^{\text {th }}$ July 2020; Accepted: $28^{\text {th }}$ September 2020

https://doi.org/10.36525/sanitas.2020.14

\begin{abstract}
The health and nutritional status of pregnant women determined at teenager and adult during a eligible woman, so everyone must have knowledge, attitudes and behaviors about nutrition so that they don't have mistakes in food selection. The purpose of this observation is determine the relationship between knowledge, attitudes, and behavior about nutritional balance with the nutritional status of students in Poltekkes Kemenkes Bengkulu in 2020. The design of this observation is obsevational cross-sectional design conducted in January in Poltekkes Kemenkes Bengkulu with a population of 640 people and a sample of 60 people. The statistical analysis used the pearson correlation test. The results showed that the average knowledge about balanced nutrition was good enough, the average attitude about balanced nutrition was good, the average behavior about balanced nutrition was good and the average nutritional status of female students was in the normal category. There is a relationship between knowledge about nutritional balance with nutritional status of student $(r=0.324)$, there is a relationship between attitudes about nutritional balance with nutritional status of student $(\mathrm{r}=0.373)$, and there is a relationship between behavior about nutritional balance with nutritional status of student $(\mathrm{r}=0.343)$. It is expected that students can improve their knowledge, attitudes and behaviors about nutritional balance.
\end{abstract}

Keywords: knowledge, attitudes, behavior, nutritional status

This is an open access journal, and articles are distributed under the terms of the Creative Commons Attribution-Non Commercial-Share Alike 4.0 License, which allows others to remix, tweak, and build upon the work non-commercially, as long as appropriate credit is given and the new creations are licensed under the identical terms. @2020 Sanitas 


\title{
HUBUNGAN PENGETAHUAN, SIKAP DAN PERILAKU TENTANG GIZI SEIMBANG DENGAN STATUS GIZI MAHASISWI DI POLTEKKES KEMENKES BENGKULU TAHUN 2020
}

\begin{abstract}
ABSTRAK
Keadaan kesehatan dan status gizi ibu hamil ditentukan pada masa remaja dan dewasa selama menjadi Wanita Usia Subur (WUS), sehingga setiap orang harus memiliki pengetahuan, sikap dan perilaku tentang gizi agar tidak menyebabkan kesalahan dalam pemilihan makanan. Tujuan penelitian untuk mengetahui hubungan antara pengetahuan, sikap, dan perilaku tentang gizi seimbang dengan status gizi mahasiswi di Poltekkes Kemenkes Bengkulu tahun 2020. Desian penelitian ini menggunakan observasional dengan rancangan cross sectional yang dilakukan pada bulan Januari di Poltekkes Kemenkes Bengkulu dengan populasi sebanyak 640 orang dan sampel 60 orang. Analisis statistik menggunakan uji pearson correlation. Hasil penelitian menunjukkan rata-rata pengetahuan tentang gizi seimbang cukup baik, rata-rata sikap tentang gizi seimbang baik, rata-rata perilaku tentang gizi seimbang baik dan rata-rata status gizi mahasiswi dalam kategori normal. Ada hubungan antara pengetahuan tentang gizi seimbang dengan status gizi mahasiswa $(r=0,324)$, ada hubungan antara sikap tentang gizi seimbang dengan status gizi mahasiswi $(\mathrm{r}=0,373)$, dan ada hubungan antara perilaku tentang gizi seimbang dengan status gizi mahasiswa $(\mathrm{r}=0,343)$. Diharapkan kepada mahasiswa dapat meningkatkan pengetahuan, sikap dan perilaku tentang gizi seimbang.
\end{abstract}

Kata Kunci: Pengetahuan, Sikap, Perilaku, Status Gizi

\section{PENDAHULUAN}

Gizi yang baik adalah pilar pembangunan dan bukan hanya karena makanan adalah kebutuhan manusia yang paling dasar. Selain itu, untuk mencapai pertumbuhan dan perkembangan fisik yang optimal, memerlukan gizi yang cukup serta aktivitas fisik untuk mendukung perkembangan otot dan kesehatan tulang (1). Gizi dapat membentuk kebiasaan makan sejak dini agar tercapai kesehatan individu yang lebih baik dimasa yang akan datang (2). Mahasiswi cenderung mudah mengikuti pengaruh teman sebayanya (3). Pengetahuan gizi yang baik secara luas dianggap sebagai aspek penting untuk mempertahankan gizi yang seimbang dan sehat (4).

Selain itu, ketidak seimbangan antara makanan yang dikonsumsi dengan kebutuhan adalah penyebab masalah gizi kurang dan masalah gizi lebih. Risiko terjadinya masalah gizi kurang dan lebih dapat terjadi karena kurangnya pengetahuan mengenai gizi seimbang. Gizi lebih atau obesitas terjadi karena ketidakseimbangan antara asupan energi dan keluaran energi dalam jangka waktu lama (5). Sikap memainkan peran penting pada status gizi (6). Sikap negatif dapat berisiko menimbulkan malnutrisi (3). Begitupun perilaku, Mahasiswi cenderung memiliki perilaku yang buruk, yang pada akhirnya 
SANITAS: JURNAL TEKNOLOGI DAN SENI KESEHATAN

ISSN : 1978-8843 (PRINT) / 2615-8647 (ONLINE)

Vol. $11(2), 2020$ : 158 - 166

mempengaruhi status gizi mereka (7). Perilaku makan tidak sehat akan berdampak pada status kesehatan dalam jangka waktu pendek maupun panjang (8). Perilaku makan tidak baik adalah kebiasaan mengonsumsi makanan yang tidak memberi semua zat-zat gizi esensial, makan tidak teratur baik waktu ataupun jenis makanan (9).

Rumusan masalah dalam penelitian ini adalah bagaimana hubungan pengetahuan, sikap dan perilaku tentang gizi seimbang dengan status gizi mahasiswi di Poltekkes Kemenkes Bengkulu Tahun 2020. Penelitian ini bertujuan untuk mengetahui hubungan pengetahuan, sikap dan perilaku tentang gizi seimbang dengan status gizi mahasiswi di Poltekkes Kemenkes Bengkulu Tahun 2020.

\section{METODE PENELITIAN}

Desain penelitian ini adalah observasional dengan rancangan cross sectional. Variabel independen yaitu pengetahuan, sikap dan perilaku tentang gizi seimbang, sedangkan variabel dependen adalah status gizi mahasiswi. Penelitian dilakukan pada Januari 2020 di Poltekkes Kemenkes Bengkulu. Populasi pada penelitian ini adalah mahasiswi jurusan keperawatan, kebidanan, analis kesehatan, kesehatan lingkungan dan promosi kesehatan tingkat I Poltekkes Kemenkes Bengkulu berjumlah 640 orang dengan perhitungan sampel mendapatkan 60 orang (10). Penelitian ini menggunakan angket/kuesioner yang telah dilakukan uji validitas, terdapat 10 pertanyaan untuk pengetahuan yang valid, 10 pertanyaan untuk sikap yang valid, dan 9 pertanyaan untuk perilaku yang valid, teknik pengumpulan data yang dilakukan dengan cara memberikan seperangkat pertanyaan kepada responden yang memberi informasi diperlukan sesuai dengan permasalahan penelitian.

Pengetahuan, sikap dan perilaku diukur dengan cara wawancara menggunakan kuesioner menggunakan skala ratio, sedangkan status gizi diukur menggunakan timbangan dan microtoice mengguanakan skala ratio. Hasil analisis univariat akan disajikan dalam bentuk tabel atau narasi. Analisis bivariat digunakan untuk menguji kemungkinan hubungan antara variabel independen (pengetahuan, sikap dan perilaku) 
SANITAS: JURNAL TEKNOLOGI DAN SENI KESEHATAN

ISSN : 1978-8843 (PRINT) / 2615-8647 (ONLINE)

Vol. $11(2), 2020$ : 158 - 166

dan variabel dependen (status gizi). Sebelum analisis data, di cek terlebih dahulu kenormalan distribusi data, analisis parametrik yang digunakan analisis uji korelasi.

\section{HASIL DAN PEMBAHASAN}

\section{Gambaran Pengetahuan, Sikap dan Perilaku tentang Gizi Seimbang dengan Status} Gizi Mahasiswi di Poltekkes Kemenkes Bengkulu Tahun 2020

Variabel independen pada penelitian ini yaitu pengetahuan, sikap dan perilaku, sedangkan variable penelitian dependen pada penelitian ini yaitu status gizi mahasiswi. Distribusi univariat digunakan untuk melihat mean, median, standar deviasi, nilai minimal dan nilai maksimal dikarenakan menggunakan skala rasio, dapat dilihat pada tabel 1.

Tabel 1 Distribusi Gambaran Pengetahuan, Sikap dan Perilaku tentang Gizi Seimbang dengan Status Gizi Mahasiswi

\begin{tabular}{llllll}
\hline Variabel & $\mathrm{n}$ & Mean & SD & Min & Max \\
\hline Pengetahuan & 60 & 5,98 & 1,14 & 4 & 8 \\
Sikap & 60 & 29,68 & 3,27 & 19 & 36 \\
Perilaku & 60 & 26,57 & 3,23 & 20 & 34 \\
IMT & 60 & 20,71 & 2,52 & 16,6 & 27,1 \\
\hline
\end{tabular}

Tabel 1 menunjukkan bahwa rata-rata pengetahuan tentang gizi seimbang cukup baik, rata-rata sikap tentang gizi seimbang baik, dan rata-rata perilaku tentang gizi seimbang baik. Rata-rata IMT mahasiswi termasuk dalam kategori status gizi normal karena masih dalam rentan IMT 18,5-25,0 kg/m2 dengan standar deviasi 2,88.

Analisis univariat pengetahuan memiliki distribusi normal dengan nilai p 0,090. Berdasarkan hasil penelitian didapatkan untuk rata-rata pengetahuan responden cukup baik, terdapat 39 responden memiliki pengetahuan yang baik. Hasil wawancara dengan responden hampir seluruh responden mengetahui lauk pauk yang dianjurkan dan sebagian besar dari responden kurang mengetahui keterangan yang tertera pada label hal ini dikarenakan responden jarang memperhatikan label yang terdapat di makanan atau minuman yang dibeli. 
SANITAS: JURNAL TEKNOLOGI DAN SENI KESEHATAN

Analisa univariat sikap memiliki distribusi normal dengan nilai p 0,130 . Berdasarkan hasil penelitian didapatkan rata-rata sikap tentang gizi seimbang responden baik, terdapat 1 responden yang memiliki sikap tidak baik. Berdasarkan hasil wawancara dengan responden sebagian kecil dari responden memiliki sikap sangat tidak setuju dengan pernyataan memperhatikan energi yang dibutuhkan, hampir sebagian dari responden tidak setuju jika tidak lupa mengonsumsi buah setiap hari, sebagian besar dari responden setuju jika mengonsumsi protein dalam makanan sehari, dan sebagian besar dari responden sangat setuju dengan pernyataan senantiasa memperhatikan kebersihan makanan.

Analisa univariat perilaku memiliki distribusi normal dengan nilai $\mathrm{p}$ 0,549. Berdasarkan hasil penelitian didapatkan rata-rata perilaku responden baik, terdapat 1 responden yang memiliki perilaku tidak baik. Berdasarkan hasil wawancara dengan responden sebagian kecil dari responden tidak pernah membeli buah-buahan menggunakan uang jajan, hampir sebagian dari responden jarang melakukan kegiatan olahraga, sebagian besar dari responden kadang-kadang membeli jajanan seperti gorengan, dan hampir sebagian dari responden selalu mencuci tangan menggunakan sabun.

Hasil analisa distribusi data status gizi memiliki distribusi normal dengan nilai $\mathrm{p}$ 0,565. Berdasarkan hasil penelitian didapatkan rata-rata IMT berada pada kategori normal. Pada usia $>18$ tahun, perhitungan status gizi menggunakan indeks masa tubuh (IMT), terdapat mahasiswi dengan status gizi dengan kategori kurus 14 responden yang mempunyai nilai paling rendah yaitu $16,6 \mathrm{~kg} / \mathrm{m} 2$, status gizi dengan kategori normal 43 respoden dan status gizi dengan kategori gemuk 3 responden yang mempunyai nilai paling tinggi yaitu $27,1 \mathrm{~kg} / \mathrm{m} 2$. 
SANITAS: JURNAL TEKNOLOGI DAN SENI KESEHATAN

ISSN : 1978-8843 (PRINT) / 2615-8647 (ONLINE)

Vol. $11(2), 2020: 158$ - 166

Hubungan Pengetahuan, Sikap dan Perilaku tentang Gizi Seimbang dengan Status

Gizi Mahasiswi di Poltekkes Kemenkes Bengkulu Tahun 2020

Analisa bivariat memiliki kategori data normal sehingga menggunakan uji parametrik yaitu uji pearson correlation untuk melihat korelasi antara pengetahuan, sikap dan perilaku dengan status gizi mahasiswi, dapat dilihat pada tabel 2 .

Tabel 2 Hubungan Pengetahuan, Sikap dan Perilaku tentang Gizi Seimbang dengan Status Gizi Mahasiswi

\begin{tabular}{lll}
\hline Variabel & $\mathrm{r}$ & $\mathrm{p}$-value \\
\hline Pengetahuan & 0,324 & 0,012 \\
\hline Sikap & 0,373 & 0,003 \\
\hline Perilaku & 0,343 & 0,007 \\
\hline
\end{tabular}

Tabel 2 menunjukkan bahwa ada hubungan yang signifikan antara pengetahuan tentang gizi seimbang dengan status gizi mahasiswi dimana nilai p-value sebesar 0,012 dan koefisien $(r)=0,324$ menunjukkan hubungan keeratan rendah. Ada hubungan yang signifikan antara sikap tentang gizi seimbang dengan status gizi mahasiswi dimana nilai p-value sebesar 0,003 dan koefisien $(r)=0,373$ menunjukkan hubungan keeratan rendah. Ada hubungan yang signifikan antara perilaku tentang gizi seimbang dengan status gizi mahasiswi dimana nilai p-value sebesar 0,007 dan koefisien $(r)=0,343$ menunjukkan hubungan keeratan rendah.

Hasil penelitian menunjukkan terdapat hubungan yang signifikan antara pengetahuan tentang gizi seimbang dengan status gizi mahasiswi $(p 0,012)$ dan diperoleh nilai $r=0,324$ menunjukkan keeratan hubungan yang rendah dan berpola positif. Nilai rata-rata pengetahuan tentang gizi seimbang di Poltekkes Kemenkes Bengkulu baik dengan ratarata status gizi di Poltekkes Kemenkes Bengkulu masuk ke dalam kategori gizi baik (11). Sama dengan penelitian yang dilakukan oleh Florence (2017) pada mahasiswa TPB Sekolah Bisnis dan Manajemen Institut Teknologi Bandung, dan penelitian yang dilakukan oleh Fitriani et al $(2020)$ pada siswa $(12,13)$. Akan tetapi penelitian ini berbeda 
SANITAS: JURNAL TEKNOLOGI DAN SENI KESEHATAN

ISSN : 1978-8843 (PRINT) / 2615-8647 (ONLINE)

Vol. $11(2), 2020$ : 158 - 166

dengan penelitian Liana et al (2017) pada mahasiswa di Akademi Kebidanan Panca Bakti Pontianak (14).

Hasil penelitian menunjukkan terdapat hubungan yang signifikan antara sikap tentang gizi seimbang dengan status gizi mahasiswi $(p$ 0,003) dan diperoleh nilai $r=0,373$ menunjukkan keeratan hubungan yang rendah dan berpola positif. Rata-rata sikap tentang gizi seimbang di Poltekkes Kemenkes Bengkulu baik. Penelitian ini sama dengan yang dilakukan oleh Mallick, et al (2017) pada sekelompok remaja perempuan di kota Howrah, Benggala Barat, dan penelitian yang dilakukan oleh Ramadhani (2017) pada mahasiswi Pondok Pesantren Wahid Hasyim Yogyakarta $(6,15)$. Akan tetapi penelitian ini berbeda dengan penelitian yang dilakukan oleh Fatharanni et al (2019) pada wanita usia subur rentang usia 19-29 tahun di kecamatan tebanggi besar (16).

Hasil penelitian menunjukkan terdapat hubungan antara perilaku tentang gizi seimbang dengan status gizi $(p 0,007)$ dan diperoleh nilai $r=0,343$ menunjukkan bahwa kekuatan hubungan yang rendah dan berpola positif. Rata-rata perilaku tentang gizi seimbang di Poltekkes Kemenkes Bengkulu baik. Sama dengan penelitian yang dilakukan oleh Yusintha and Adriyanto (2018) pada remaja putri, dan penelitian yang dilakukan oleh Ramadhani (2017) pada mahasiswi Pondok Pesantren Wahid Hasyim Yogyakarta $(15,17)$. Akan tetapi penelitian ini berbeda dengan penelitian yang dilakukan oleh Fatharanni et al (2019) pada wanita usia subur di kecamatan tebanggi besar (16).

\section{SIMPULAN}

Berdasarkan hasil penelitian dan pembahasan maka didapat kesimpulan sebagai berikut:

a. Rata-rata pengetahuan tentang gizi seimbang mahasiswi di Poltekkes Kemenkes Bengkulu yaitu 5,96. Rata-rata sikap tentang gizi seimbang mahasiswi di Poltekkes Kemenkes Bengkulu yaitu 29,68. Rata-rata perilaku tentang gizi seimbang mahasiswi di Poltekkes Kemenkes Bengkulu yaitu 26,57. Rata-rata status gizi mahasiswi di Poltekkes Kemenkes Bengkulu termasuk kedalam kategori status gizi normal yaitu 20,71. 
b. Ada hubungan yang signifikan antara pengetahuan tentang gizi seimbang dengan status gizi mahasiswi dengan nilai $\mathrm{r} 0,324$.

c. Ada hubungan yang signifikan antara sikap tentang gizi seimbang dengan status gizi mahasisiwi dengan nilai r 0,373 .

d. Ada hubungan yang signifikan antara perilaku tentang gizi seimbang dengan status gizi mahasiswi dengan nilai r 0,343 .

Disarankan bagi mahasiswi bisa lebih mengenal gizi seimbang dengan cara mengukuti sosialisasi mengenai gizi seimbang agar memiliki sikap dan perilaku yang baik, karena perilaku memiliki dampak terhadap status gizi serta meningkatnya pengetahuan dan sikap mahasiswi tentang gizi seimbang secara tidak langsung akan memiliki dampak terhadap status gizi. Serta peneliti selanjutnya diharapkan adanya penelitian lebih lanjut tentang pengetahuan, sikap dan perilaku gizi seimbang dengan status gizi dengan lebih mempertimbangkan faktor-faktor lainnya seperti aktivitas fisik

\section{UCAPAN TERIMA KASIH}

Terima kasih kepada Direktur dan civitas akademika Poltekkes Kemenkes Bengkulu atas dukungan moril dalam pelaksanaan penelitian ini.

\section{DAFTAR PUSTAKA}

1. Perveen R, Raiz A, Khan UM. Assessing The Influence Of Nutrition Education Among Adolescent Girls (13-16 Years). Adv Obes Weight Manag Control. 2017;6(4):144-7.

2. Damayanti AY, Fathimah, Setyorini IY. Gambaran Tingkat Pengetahuan Gizi Seimbang Pada Santriwati Remaja Putri Di Pondok Pesantren. Darussalam Nutr J. 2018;2(2):1-5.

3. Nuryani, Paramata Y. Intervensi Pendidik Sebaya Meningkatkan Pengetahuan, Sikap, Dan Perilaku Gizi Seimbang Pada Remaja Di MTsN Model Limboto. Indones J Hum Nutr. 2018;5(2):96-112.

4. Calella P, Iacullo VM, Valerio G. Validation Of A General And Sport Nutrition Knowledge Questionnaire In Adolescents And Young Adults: GeSNK. Nutrients. 2017;9(493):1-12.

5. Sazani A. Efektivitas Media Nutrizan Diet Untuk Meningkatkan Pengetahuan Tentang Diet Yang Sehat Pada Remaja Putri SMK Jurusan Kecantikan Di Kota Tegal. J Heal Educ. 2016;1(2):8-12.

6. Mallick N, Mukhopadhyay S, Ray S. Eating Attitudes And Its Relationship With Nutritional Status : A Micro Level Study On A Group Of Adolescent Girls In The City Of Howrah, West Bengal. Int J Adolesc Med Health. 2017;1-8. 
SANITAS: JURNAL TEKNOLOGI DAN SENI KESEHATAN

7. Haq I, Mariyam Z, Li M, Huang X, Jiang P, Zeb F, et al. A Comparative Study Of Nutritional Status, Knowledge Attitude And Practices ( KAP ) And Dietary Intake Between International And Chinese Students In Nanjing, China. Int J Environ Res Public Health. 2018;15(1910):1-11.

8. McLaunghim M. Kesehatan Reproduksi Remaja. Jogjakarta: Banyu Media; 2014.

9. Sarintohe P. Teori Sosial Kognitif Dalam Menjelaskan Perilaku Makan Sehat Pada Anak Yang Mengalami Obesitas. Bandung: Sosiains; 2016.

10. Lemeshow S, Hosmer DW, Klar J. Adequacy Of Sample Size In Health Studies. World Health Organization by Jhon Wiley \& Sons; 1990. 54 p.

11. PERSAGI, AsDI. Penuntut Diet Dan Terapi Gizi. 4th ed. Jakarta: EGC; 2019.

12. Florence AG. Hubungan Pengetahuan Gizi Dan Pola Konsumsi Dengan Status Gizi Pada Mahasiswa TPB Sekolah Bisnis Dan Manajemen Institut Teknologi Bandung. Universitas Pasundan Bandung; 2017.

13. Fitriani R, Dewanti LP, Kuswari M, Gifari N, Wahyuni Y. Hubungan Antara Pengetahuan Gizi Seimbang, Citra Tubuh, Tingkat Kecukupan Energi Dan Zat Gizi Makro Dengan Status Gizi Pada Siswa. Gorontalo J Heal Sci Community. 2020;4(1):29-38.

14. Liana AE, Soharno, Panjaitan AA. Hubungan Antara Pengetahuan Tentang Gizi Seimbang Dengan Indek Masa Tubuh Pada Mahasiswa. J Kebidanan. 2017;7(2):132-9.

15. Ramadhani stevia tafdhila. Hubungan Perilaku Konsumsi Makanan Sehat Dengan Status Gizi Mahasiswi Pondok Pesantren Wahid Hasyim Yogyakarta. J Pendidik Tek boga. 2017;81-8.

16. Fatharanni MO, Angraini DI, Oktaria D. Hubungan Pengetahuan, Sikap Dan Perilaku Mengenai Gizi Seimbang Dengan Status Gizi Pada Wanita Usia Subur Di Kecamatan Terbanggi Besar Kabupaten Lampung Tengah. Medula. 2019;9(1):26-37.

17. Yusintha AN, Adriyanto. Hubungan Antara Perilaku Makan Dan Citra Tubuh Dengan Status Gizi Remaja Putri Usia 15-18 Tahun. Amerta Nutr. 2018;147-54. 